\title{
Do diário ao romance: ficcionalizando uma experiência-limite
}

Lima Barreto. Diário do hospício e O Cemitério dos vivos. Prefácio de Alfredo Bosi. Organização e notas de Augusto Massi e Murilo Marcondes de Moura. São Paulo: Cosac Naify, 2010. 352 p., 24 ils.

“Ler os livros de Lima Barreto é de alguma forma participar do drama do intelectual sitiado. Mais talvez do que isso, é um exercício de consciência histórica que conta com a vantagem, como poucas noutro escritor brasileiro, de um difícil testemunho: constatar como a vida, e nesta a opressão e o fracasso, se converte em literatura."

Se a obra do escritor, particularmente a romanesca, é perpassada por um fio autobiográfico, o livro ora em tela pode ser considerado a expressão maior dessa característica e também da interpretação feita pelo crítico citado aqui, Antonio Arnoni Prado, nos anos 1970, período no qual os estudos sobre a obra de Lima Barreto começaram a ganhar espaço no âmbito universitário.

Em 25 de dezembro de 1919 Lima Barreto é internado pela segunda vez no Hospício Nacional de Alienados, onde permanecerá até 02 de fevereiro de 1920, e novamente ali chegou pelas mãos da polícia. ${ }^{2}$ Em 04 de janeiro de 1920 começa a escrever o Diário do hospício, e uma de suas primeiras anotações é justamente sobre o poder que a nossa Primeira República conferia ao aparelho policial para decidir quem era meliante e quem era louco: "Não me incomodo muito com o Hospício, mas o que me aborrece é essa intromissão da polícia na minha vida". ${ }^{3}$

No dia 31 do referido mês, em entrevista para o jornal $A$ Folha, adianta ao repórter que pretende escrever um livro sobre os hospitais de loucos: "leia O cemitério dos vivos. Nessas páginas contarei, com fartura de pormenores, as cenas mais jocosas e

1. PRAdo, Antonio Arnoni. Lima Barreto: o crítico e a crise. São Paulo: Martins Fontes, 1989, p. 3.

2. A primeira internação ocorrera entre 18 de agosto e 13 de outubro de 1914.

3. barreto, Lima. Diário do hospício e o Cemitério dos vivos. Prefácio de Alfredo Bosi. Organização e notas de Augusto Massi e Murilo Marcondes de Moura. São Paulo: Cosac Naify, 2010. 352 p., 24 ils., p. 44. Todas as demais citações que aparecerão ao longo da resenha são da mesma edição.

246. MAGNONI, Maria Salete. Do diário ao romance... 
as mais dolorosas que se passam dentro dessas paredes inexpugnáveis. Tenho visto coisas interessantíssimas". O primeiro capítulo de O cemitério dos vivos foi publicado em janeiro de 1921 na Revista Souza Cruz (número 49), sob o título As origens e com o autor ainda vivo, mas Lima Barreto não concluiu o romance, pois faleceu pouco mais de um ano depois, em novembro de 1922.

A primeira edição do Diário do hospício/ O cemitério dos vivos foi feita pela editora Mérito em 1953. Nela há uma breve nota introdutória de Francisco de Assis Barbosa, autor da importante biografia A vida de Lima Barreto, 1881-1922 (Rio de Janeiro: José Olympio, 1952; 9. ed., 2003). Apresenta o seguinte índice: Diário, Diário do hospício (apontamentos), O cemitério dos vivos (fragmentos) e Inventário da Biblioteca -, sendo a versão do Diário do hospício bastante reduzida. ${ }^{4}$ Foi também nos anos 1950 que a editora Brasiliense, de propriedade do historiador paulista Caio Prado Júnior, adquiriu da família do escritor os direitos autorais de sua obra. E assim, sob a direção de Francisco de Assis Barbosa, Antônio Houaiss e Manoel Cavalcanti Proença, pela primeira vez foi publicada a obra completa de Lima Barreto, na qual o volume XV se intitula $O$ cemitério dos vivos (Fragmentos) e traz o texto integral do romance inacabado. Antecedido pelo Diário do hospício (apontamentos), contém ainda o Inventário (Coleção Limana, nome que Lima Barreto deu à sua biblioteca), a entrevista para o jornal $A$ Folha e cópias de três registros médicos, relativos ao caso clínico de Lima Barreto, nas duas vezes em que esteve internado no Hospício Nacional de Alienados.

Em 1988 a Secretaria de Cultura da Cidade do Rio de Janeiro, através de sua Coleção Biblioteca Carioca, com organização de Ana Lúcia Machado de Oliveira, Diva Maria Dias Graciosa e Rosa Maria de Carvalho Gens, publicou uma edição do Diário do hospício e de O cemitério dos vivos que contém como anexo o conto "Como o homem chegou", escrito por Lima Barreto ao sair de sua primeira internação no hospício em 1914. Organizado por Bernardo de Mendonça, a Graphia Editorial publicou também em 1993 Um longo sonho de futuro: diários, cartas, entrevistas e confissões dispersas, que reúne os chamados textos autobiográficos do romancista, e obviamente traz o Diário do hospício.

Com prefácio do crítico Fábio Lucas, a edição de $O$ cemitério dos vivos publicada pela Planeta em 2004 tem a mesma estrutura da edição da Brasiliense, com o diferencial de novas notas, introduzidas pelo organizador Diogo de Hollanda, que fez também o cotejo do texto estabelecido por Francisco de Assis Barbosa com as anotações que

4. A informação me foi dada por Augusto Massi, pois não tive acesso à referida edição. 
constituem o Diário do hospício e que estão na Seção de Manuscritos da Biblioteca Nacional no Rio de Janeiro.

Mas é com a edição conjunta, organizada por Augusto Massi e Murilo Marcondes de Moura, publicada em 2010 pela Cosac Naify, que o Diário do hospício e O cemitério dos vivos retornam ao seu leito de origem. A edição, que não se pretende crítica, como assinalam seus organizadores, é ilustrada com fotos de época e teve o seu texto cotejado com os manuscritos originais e também com as melhores edições existentes. Sua qualidade é vista logo no prefácio, pois no ensaio "O cemitério dos vivos: testemunho e ficção"s o crítico Alfredo Bosi faz uma análise histórico-literária da obra, trazendo à tona temas que se expandem para além das intenções do próprio texto de Lima Barreto. Exemplifico com a leitura do trecho de O cemitério dos vivos no qual o escritor através do personagem Vicente Mascarenhas descreve o carro forte que o conduzira ao hospício. Bosi, ao nos remeter à discussão do binômio barbárie/ civilização, anota que esse conluio não é privilégio do Brasil, embora muitos se comprazam (e enfaticamente nesses dias que estamos vivendo) em afirmar o contrário. Escreveu o crítico:

A denúncia veio da Europa e está presente, apesar das diferenças de horizonte político, em Swift, Schopenhauer, Burckhardt, em Engels, em Marx, em Dostoiévski, em Walter Benjamin, em Ortega y Gasset, em Simone Weil, em Brecht; é um dos tópicos mais ardidos da crítica da cultura que escapou aos horrores do nazismo, soube avaliar a tempo os do stalinismo, mas igualmente armou suas antenas para captar os signos da brutalidade, cinismo e eficiência técnica emitidos pela civilização de massas de tipo americano que prevaleceu no Ocidente a partir da Segunda Guerra. (p. 36).

Assinala também que, embora a literatura brasileira conte com inúmeros registros memorialísticos e autobiográficos, "são raras as obras que possam valer como testemunhos diretos e coerentes de um estado de opressão e humilhação. Este é o caso do Diário do Hospício de Lima Barreto" (p. 11). ${ }^{6}$

Alfredo Bosi diz se impressionar com o efeito da "serena lucidez que sai das páginas escritas em um asilo de alienados" (p. 11), cuja prosa de andamento moderado, linguagem

5. Segundo Augusto Massi em entrevista concedida na ocasião do lançamento da edição, foi a partir do ensaio de Alfredo Bosi que surgiu a ideia de reeditar o livro. Disponível em: $<$ http://www.saraivaconteudo.com.br/Materias/Post/10423 >

6. No original está com $\mathrm{H}$. 
transparente e aparentemente sem surpresas não implica prejuízos para a observação crítica, questionamentos e denúncias presentes em cada frase. Mas o leitor será surpreendido pela mudança de registro, ou seja, pelo momento em que o que parecia ser a simples transcrição do dia a dia de um interno em um hospício cede passo à ficção. Essa mudança se dá "no exato momento em que o depoente entra a escavar o passado e aprofundar a sua 'angústia de viver”'. (p. 26). À matéria-prima do diário acrescentaram-se os recursos da invenção romanesca, pois há nas páginas de $O$ cemitério dos vivos personagens e fatos que não fazem parte da história pessoal do escritor, como esposa e filho. A inventiva ficcional de um casamento frustrado parece ser, de acordo com o crítico, uma necessidade de Lima Barreto "transpor para a esfera do imaginário [...] o seu drama fundamental de saber-se capaz de uma alta produção literária ao mesmo tempo que era oprimido por um conjunto de condições sociais adversas" (p. 30). Bosi, leitor contumaz de Lima Barreto, lamenta: "A novela ficou inacabada. Foi pena, pois a substância autobiográfica (evidente nos episódios transpostos das páginas do diário) começava a resolver-se em prosa enxuta e pensada, só comparável às boas passagens dos romances do autor levados a termo" (p. 29).

A completar a qualidade do ensaio que originou a edição, temos a pesquisa levada a cabo pelos organizadores, que se traduziu em notas que contextualizam historicamente pessoas/personagens que de algum modo se relacionaram com o escritor, ilustram e explicam aspectos de sua vida e até mesmo suas escolhas. À guisa de exemplo cito a nota de número $2 \mathrm{O}^{7}$ de $O$ cemitério dos vivos: ela indica o livro do qual Lima Barreto teria retirado a ideia para o título do seu romance; todas as outras edições também o citam, mas o que nenhuma trouxe é que o referido livro é ilustrado com imagens de um cemitério. A descoberta de que até então vinha se publicando incorretamente o nome de um livreiro, informação constante na nota número 62 do Diário do hospício, embora pareça a simples correção de um nome, dá outro caráter interpretativo ao gosto de Lima Barreto pela leitura de Júlio Verne. Escreve ele no Diário: "A minha literatura começou por Jules Verne, cuja obra li toda. Aos sábados, quando saía do internato, meu pai me dava uma obra dele, comprando no David Corazzi, na rua da Quitanda. Custavam mil-réis o volume, e os lia, no domingo todo, com afã e prazer inocente" (pp. 102-3). Ocorre que o livreiro até a presente edição era apresentado como Daniel Corazzi, o que impediu que soubéssemos quem ele foi de fato. Dono da importante Casa Editora David Corazzi em Lisboa e com filial no Rio de Janeiro, era reconhecido

7. A China e os Chins: recordações de viagens, de Henrique C. R. Lisboa (Montevidéu: A. Godel, 1888). 
pela qualidade de suas edições ilustradas. Se pensarmos em Lima Barreto garoto, filho de um pai apenas remediado, que se esforçava para comprar para o filho toda a obra de Verne editada com tanto esmero, entendemos o seu prazer e alegria em ganhar tais livros e mesmo o gesto de mencionar o preço.

Outro aspecto importante e também ampliado nesta edição do Diário do hospício e $O$ cemitério dos vivos diz respeito aos médicos e psiquiatras que atuavam no Hospício Nacional de Alienados. Lima Barreto deles desconfiava e desdenhava de suas capacidades, principalmente para entender a natureza humana. Ademais, alguns deles eram metidos a literatos, o que fazia aumentar a sua implicância. Os organizadores, através de notas, contextualizam historicamente esses médicos e desfazem equívocos seguidamente repetidos. E na primeira parte do apêndice existente no final do livro, "O hospício - segundo Lima Barreto", em duas das crônicas publicadas, o escritor cita nominalmente dois desses médicos, Humberto Gotuzzo e Juliano Moreira, de forma bastante amigável e afetuosa, o que matiza sua aversão aos alienistas.

A edição resgata ou apresenta, e isso a torna ainda mais interessante, o debate que houve em torno do Hospício Nacional de Alienados à época de sua reinauguração na República Velha. Na segunda parte do apêndice, "O hospício - segundo outros cronistas", as crônicas de Machado de Assis, Olavo Bilac e Raul Pompeia o revelam. Assim, o tema hospício/loucura deixa de ser um drama individual de Lima Barreto e é (re)colocado no seio da literatura brasileira do período.

Concluindo, penso que essa reedição do Diário do hospício e O cemitério dos vivos contribui para se avançar na compreensão do projeto literário de Lima Barreto, pois, ao acrescentar à publicação alguns de seus escritos relacionados às suas experiências de internações no hospício, os organizadores propiciam aos leitores/pesquisadores o conhecimento dos procedimentos literários que permitem entender melhor o processo criativo que culmina com O cemitério dos vivos. Imaginamos que essa leitura estimule os leitores/ pesquisadores a procurarem em toda a obra de Lima Barreto as pistas do processo criativo que lhe permitiu transfundir a realidade em ficção sem trair a sua complexidade.

Maria Salete Magnoni é doutora em Literatura Brasileira pela Universidade de São Paulo e pós-doutoranda no Departamento de Teoria e História Literária do IEL/ Unicamp sobre a obra de Lima Barreto. 